DR DAVID ROBIE is editor of

Pacific Journalism Review.

\section{Drone killings on a par with mafia hitmen}

We Kill Because We Can: From Soldiering to Assassination in the Drone Age, by Laurie Calhoun. London: Zed Books. 2016. 400pp. ISBN 978-1-78360$547-7$ pbk.

$\mathrm{O}$ $\mathrm{NE}$ of the ironies of the legacy of eight years of Barak Obama's presidency is that under the leadership of the man who was elected to bring a more peaceful world into play following George W. Bush's warmongering, the 'global war on terror' (GWOT) has grown enormously.

Remote control warfare by drones with virtually no transparency is deeply disturbing. After years of demands for statistics about the drone killing programme, Obama was finally forced to admit in April 2013 that an American, Dr Warren Weistein, and an Italian, Giovanni Lo Porto, had been 'tragically killed' in a counter-terrorism operation by drone strike three months earlier in Pakistan (Ackerman, 2016).

This rare admission of guilt over the drone programme confirmed suspicions about a climbing death toll among civilians.

While the US target is claimed to be al-Qaeda and Daesh (the self-styled Islamic State, ISIS or ISIL) suspects, research by the London-based Bureau

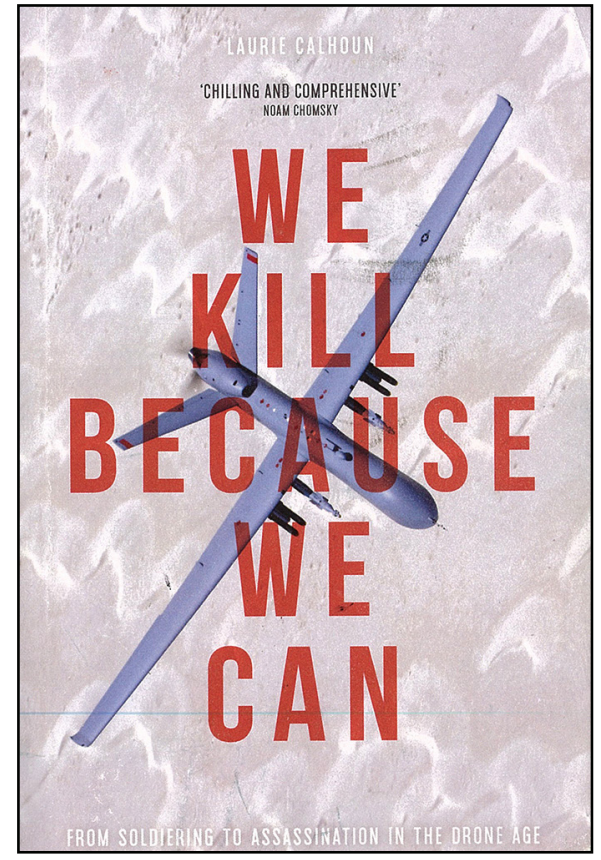

of Investigative Journalism has demonstrated that during Obama's tenure more than 7000 people have been killed with impunity by drone controllers far from any battlefield.

About a seventh of these deaths are estimated to be civilians, including up to 110 children.

This death toll contrasts greatly with a mere 54 drone strikes authorised by President Bush in his entire term of office.

And undoubtedly the billionaire businessman and reality television tycoon President, Donald Trump, will entrench the use of drones even further.

This timely book, provocatively entitled We Kill Because We Can (adapted from a quote by a drone operative), has exposed the ethical and moral bankruptcy and shortsighted objectives of the Predator drone programme. 
Author Laurie Calhoun, a philosopher and cultural critic, has penned a robustly argued and disturbing work that presents an analogy between the US government's 'targeted killings' and the mafia's hitmen murders, lumping the Bush and Obama drone killings together as 'simply assassinations'.

Calhoun likens suspects chosen for the growing weekly 'killing lists' to a stay on death row, with no provision for an appeal or re-examination of the evidence that led to the 'conviction'.

Yet it is well known that suspects charged with capital crimes within civil society are often acquitted, as the evidence proves unconvincing to a jury of their peers. Jurors in US criminal trials are sternly instructed by the court that a verdict of guilty must be established beyond a reasonable doubt. (p. 120)

Calhoun argues that the 'slick technological apparatus' enabling drone strikes serves as a red herring that diverts attention from the crucial question - is it actually true that people about to die by remote control via a Hellfire missile are guilty of some capital crime and 'deserve to die'?

As the author stresses, drone strikes are irrevocable. Yet even in countries where the US is not officially at war and there are no ground troops 'to protect', the state emphasis is on killing the target.

The killings are treated as 'acts of war', but they are 'indistinguishable from unlawful assassination', says Calhoun, and they overlap with warfare actions only in the 'effective impunity of the killers' (p. 120).

Calhoun also offers a scathing critique of the military-industrial complex and its phenomenal growth since former US Vice-President Dick Cheney began privatising and outsourcing to contractors during the occupation of Iraq.

The military machine virtually guarantees the continued use of drones and the self-justifying killings as part of a burgeoning 'terror factory' (p. 245). The number of new Predator operators trained in the US quadrupled between 2008 and 2013 and this figure eclipses the number of conventional pilots being trained.

The hardware alone of the drone programme is a huge contract generator. As of 2013, the drone contracts for major weapons manufacturers were at these figures: Boeing $\$ 1.8$ billion; Northrop Grumman \$10.9 billion; General Atomics $\$ 6.6$ billion; and Raytheon $\$ 648$ million. (p. 243)

Calhoun is highly critical of the role of news media in failing to expose the Orwellian mythology and 'just war' terminology shrouding GWOT, and of also failing to provide greater transparency about the drone industry; the inherent conflicts of interest; the dangers of exporting the killing technology to other countries (at least 19 so far) and the role played by targeted killing in unleashing revenge acts by jihadists.

She ultimately argues that the indifference demonstrated by the US 
towards the "thousands of nameless victims, [or] the corruption caused directly by war' risks inviting another terrorist atrocity equally as audacious as $9 / 11$ (p. 334).

\section{Reference}

Ackerman, S. (2016, July 1). Obama claims US drones strikes have killed up to 116 civilians. The Guardian. Retrieved from https://www.theguardian.com/ us-news/2016/jul/01/obama-dronesstrikes-civilian-deaths
DR JAMES HOLLINGS is a senior lecturer in journalism at Massey

University.

\section{Valiant on digital media, lacking on indigeneity}

Media and Journalism: New Approaches to Theory and Practice [3rd ed.], edited by Jason Bainbridge, Nicola Goc and Liz Tynan. Melbourne: Oxford University Press., 2015. 504 pp. ISBN 9-780-1955-8801-9.

$\mathrm{T}$ HIS IS an updated version of a wellestablished media text by three prominent Australian media academics. Like the first edition, it is aimed at beginner media studies students,
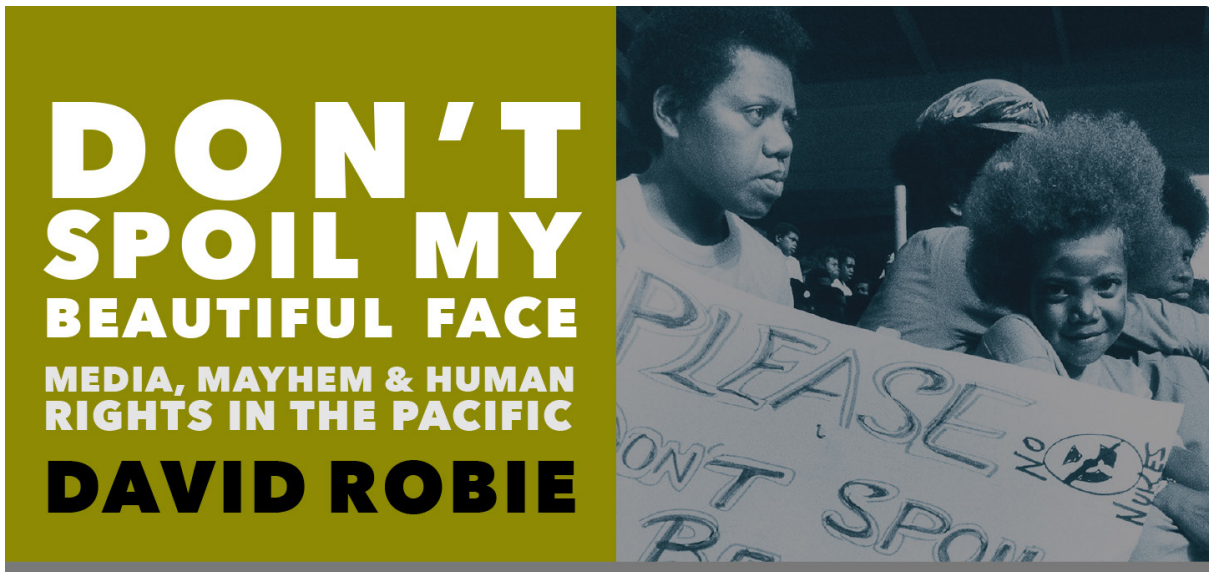

"This is an extraordinary 'secret history' of a vast region of the world of which David Robie has been a rare expert witness. What makes this epic work so timely is that it allows us to understand the Asia-Pacific at a time of renewed cold war ambitions and dangers." - John Pilger

little island press • ISBN 978-1-877484-25-4 • www.littleisland.co.nz 